\title{
PELATIHAN KURIKULUM 2013 GURU SEKOLAH DASAR DI SDI FATUKOAN KECAMATAN RINHAT KABUPATEN MALAKA
}

\author{
1)Nuriyah, 2) Fenny Tanalinal Khasna, 3) Ummu Fajariyah Akbari, 4) Budi Kurniawan, \\ 5)Uslan, ${ }^{6}$ Sunimbar \\ Program Studi PGSD, Universitas Muhammadiyah Kupang \\ 1) nuriyahbadjo@yahoo.co.id, ${ }^{2)}$ fennytanalinal@gmail.com ${ }^{3)}$ ummuuakbarii@gmail.com \\ ${ }^{4)}$ kurniawanbudi012@gmail.com, ${ }^{5}$ uslanspd@gmail.com, ${ }^{6}$ sunimbar@gmail.com
}

\section{Histori artikel}

Received:

7 November 2020

Accepted:

29 November 2020

Published:

30 November 2020

\begin{abstract}
Abstrak
Tujuan pelatihan kurikulum 2013 bagi guru SDI Fatukoan ini diharapkan dapat meningkatkan kemampuan guru tentang: (1) model pembelajaran dalam kurikulum 2013; (2) strategi dan pendekatan model pembelajaran dalam implementasi kurikulum 2013; (3) memaparkan materi tentang penguatan pengembangan soal diagnostik; (4) materi tentang penyusunan Rencana Pelaksanaan Pembelajaran (RPP); (5) tanya jawab tentang materi yang telah disampaikan terkait Kurikulum 2013 (6) menyusun perangkat pembelajaran. Pelaksanaan kegiatan pengabdian melalui pelatihan kurikulum 2013 berjalan sesuai dengan program yang telah direncanakan. Metode pelaksanaan yang digunakan dalam kegiatan pengabdian masyarakat ini dibagi menjadi 4 (empat) tahapan meliputi (1) observasi awal daerah kegiatan (2) pemetaan masalah (3) sosialisasi kegiatan (4) penyelenggaraan pelatihan dengan melibatkan guru-guru SDI Fatukoan,dan dosen Prodi PGSD Universitas Muhammadiyah Kupang. Outcome yang diperoleh dari kegiatan ini adalah adanya pemahaman guru-guru tentang implementasi kurikulum 2013 serta pengembangan soal diagnostik serta media pembelajaran.
\end{abstract}

Kata-kata Kunci: pelatihan kurikulum, guru SD 
Abstract. The objectives of the 2013 curriculum training for SDI Fatukoan teachers are expected to improve teachers' abilities regarding: (1) learning models in the 2013 curriculum; (2) learning model strategies and approaches in the implementation of the 2013 curriculum; (3) presenting material on strengthening the development of diagnostic questions; (4) material on the preparation of a Learning Implementation Plan (RPP); (5) questions and answers regarding the material that has been submitted about the 2013 Curriculum (6) compiling the learning tools. The implementation of community service activities through curriculum 2013 training goes according to the planned program. The implementation method used in community service activities is divided into 4 (four) stages including (1) initial observation of the activity area (2) mapping the problem (3) socialization of activities (4) organizing training by involving teachers of SDI Fatukoan and lecturers of the Primary Teacher Education Program, University of Muhammadiyah Kupang. The outcome obtained from this activity was the teacher's comprehension about the implementation of the 2013 curriculum and the development of diagnostic questions and learning media.

Kata-kata Kunci: curriculum training, elementary teacher

\section{PENDAHULUAN}

Pendidikan Nasional mempunyai visi terwujudnya sistem pendidikan sebagai pranata sosial yang kuat dan berwibawa untuk memberdayakan semua warga negara Indonesia berkembang menjadi manusia yang berkualitas sehingga mampu dan proaktif menjawab tantangan zaman yang selalu berubah (Uslan dkk., 2020). Kurikulum merupakan salah satu instrument yang diharapkan memberikan arah untuk mewujudkan proses berkembangnya kualitas potensi peserta didik untuk menjadi insan yang berkualitas serta mampu bersaing di tengah tuntutan zaman.Olehkarena itu, kurikulum disusun dan dikembangkan serta dapatdigunakan sebagai pemandu sebelum memulai aktifitas pembelajaran (Yasinta \& Ummu, 2020).Kurikulum 2013 adalah sebagian dari kurikulum yang diterapkan serta diputuskan oleh Kementrian Pendidikan dan Kebudayaan Republik Indonesia. Walaupun masih banyak sekolah yang belum meenerapkannya kurikulum ini, namun kurikulum 2013 sudah secara resmi diberlakukan mulai tahun ajaran 2014-2015. Disahkannya kurikulum ini sebagai pengganti dari kurikulum sebelumnya yakni Kurikulum Tingkat Satuan Pendidikan(KTSP), dan diharapkan dari kurikulum baru adalah capaian yang lebih diharapkan yakni memacu kreativitas peserta didik yang aktif bukan hanya guru yang mendominasi selama pembelajaran berlangsung(Suryadin \& Arifin, 2020). Jika seorang pendidik mampu berfikir jernih dan besedia merubah paradigma dalam menghayati sistem pendidikan nasional dan menyadari tantangan

global, maka impementasi kurikulum 2013 tidak menjadikan beban yang berlebihan bagi guru dan sekolah.

Oleh karena itu untuk mendukung jalannya paradigma dalam dunia pendidikan sekarang ini sudah harus memiliki cara pandang bahwa kompetensi masa depan yang diperlukan dalam menghadapi arus globalisasi antara lain, memiliki kecerdasan spiritual yang 
baik, memiliki kemampuan berkomunikasi, kemampuan berpikir jernih dan kritis. Sehingga untuk mendukung terlaksananya kurikulum 2013 maka seorang guru harus berinovasi seperti mengenal dan terbiasa menerapkan model-model pembelajaran di dalam kelas, dan salah satu model yang di ditawarkan pada guru-guru dalam pelatihan kurikulum 2013 ini adalah pembelajaran berbasis proyek. Team memilih model pembelajaran berbasis proyek dikarenakan model Pembelajaran Berbasis Proyek (PBP) merupakan strategi pembelajaran yang menggunakan proyek/kegiatan sebagai sarana pembelajaran untuk mencapai kompetensi sikap, pengetahuan dan keterampilan. Penekanan pembelajaran terletak pada aktivitas peserta didik untuk memecahkan masalah dengan menerapkan keterampilan meneliti, menganalisis, membuat, sampai dengan mempresentasikan produk pembelajaran berdasarkan pengalaman nyata. Team PKM memberikan materi tentang PBP dikarenakan sesuai dengan penelitian (lis \& Wahyu, 2016) yang mengemukan bahwa pembelajaran berbasis proyek dapat meningkatkan sikap ilmiah lebih tinggi secara signifikan terhadap siswa sekolah dasar.

Selain memberikan materi tentang model pembelajaran untuk mendukung kurikulum 2013 team PKM Program Studi Pendidikan Guru Sekolah Dasar (PGSD) Universitas Muhammadiyah Kupang sesuai dengan permasalahan yang ditimbulkan setelah melakukan wawancara sebelum kegiatan pengabdian masyarakat berlangsung di SDI tersebut adalah guruguru yang pernah mengikuti pelatihan kurikulum 2013 cuman sekali sehingga pemahaman serta penerapannya belum maksimal oleh karena itu team juga memaparkan materi tentang penguatan pengembangan soal diagnostik sebagai penguatan penilaian aspek kognitif yang disampaikan oleh Sunimbar, M.Pd. dan Fenny Tanalinal, M.Pd. Dalam paparan pemateri memberikan pengarahan kepada guru-guru SDI Fatukoan untuk melakukan tes diagnostik kepada peserta didik untuk mengidentifikasi masalah-masalah atau kelemahan-kelemahan pembelajaran yang dihadapi oleh siswa. Dengan demikian, guru dapat memberikan tindak lanjut berupa perlakuan pembelajaran yang sesuai dengan kebutuhan siswa.

Dalam kesempatan ini juga, pemateri berdua mengemukakan tahapan dalam melaksanakan tes diagnostik yang meliputi 1) mengidentifikasi KD yang belum tuntas, 2) menentukan kemungkinan sumber masalah, 3) menentukan bentuk dan jumlah soal yang sesuai, 4) menyusun kisi-kisi soal, 5) menulis soal, 6) mereviu soal, dan 7) menyusun kriteia penilaian. Tahapan tersebut menjadi acuan dalam mengimplementasikan tes diagnostik untuk siswa. Sebagai upaya tindak lanjut penguatan pelatihan ini, para pemateri memberikan lembar kerja guru untuk dikerjakan sebagai upaya tindak lanjut menguatkan pemahaman materi yang sudah disampaikan para pemateri. Guru-guru SD peserta penguatan penilaian pembelajaran 
sangat antusias dengan kegiatan ini dan banyak melakukan diskusi terhadap materi-materi yang diutarakan baik model pembelajaran ataupun mengenai pelaksanaan tes diagnostik serta dari kegitan ini diharapkan guru-guru dapat membuat perangkat pembelajaran terpadu tematik berdasarkan kaidah kurikulum 2013 untuk wadah peningkatan kualitas guru, serta pengabdian masyarakat ini juga bisa memberikan pengetahuan dan ketrampilan tambahan bagi guru-guru untuk diterapkan dalam pembelajaran di kelas.

\section{METODE PELAKSANAAN}

Metode pelaksanaan yang digunakan dalam kegiatan pengabdian masyarakat ini dibagi menjadi 4 (empat) tahapan meliputi (1) observasi awal daerah kegiatan (2) pemetaan masalah (3) sosialisasi kegiatan (4) penyelenggaraan pelatihan dengan melibatkan guru-guru SDI Fatukoan, dosen dan mahasiswa Prodi PGSD Universitas Muhammadiyah Kupang. Kegiatan pengabdian ini dilaksanakan dari tanggal 16 sampai dengan 17 Oktober 2020.Media dan alat yang digunakan berupa LCD proyektor, slide power point dan pengeras suara serta pedoman teentang kurikulum 2013. Dengan urutan pelaksananaan mengacu pada (Muhammad, 2019) yaitu, Pemaparan materi tentang undang-undang/peraturan pemerintah tentang Kurikulum2013 dan rasional kurikulum, Materi Penyusunan Rencana Pelaksanaan Pembelajaran (RPP) Kurikulum 2013 dan Timpengabdianmendampingi gurudalam menyusun perangkat pembelajaranyang sesuaidengankurikulum2013. Analisis data menggunakan pendekatan deskriptif kuantitatif yang sekaligus mengutarakan permasalahan yang dihadapi guru-guru di SDI Fatukoan serta mengidentifikasi kendala lainnya yang dihadapi sekolah dalam mengimplementasikan kurikulum 2013.

\section{HASIL DAN PEMBAHASAN}

\section{Hasil}

Pada awal kegiatan ini kepala sekolah SDI Fatukoanmemberikan sambutan sekaligus membukakegiatan pelatihan Kurikulum2013. Dalam sambutannyabeliau berpesan agar para pesertabisa mengikuti pelatihantersebut sampai selesai.Selanjutnya Tim Pelaksana kegiatan pengabdian masyarakat mengucapkanterima kasihatas sambutan dan diberikannya izin melaksanakan pengabdian di sekolah tersebut.

Dalam pelaksanaan kegiatan pelatihan ini strategi yang digunakan adalah dengan cara memberikan materi dan pendampingan secara tahap demi tahap. Dimulai dari pengenalan 
sampai nanti ke tahap bagaimana pembuatan perangkat pembelajaran kurikulum 2013. Langkah-langkah pelaksanaan-nya adalah sebagai berikut:

1. Metode yang digunakan dalam kegiatan ini adalah presentasi dan pendampingan. Adapun materi yang disampikan tim pelaksana terkait tentang undang-undang/ peraturan pemerintah tentang kurikulum 2013 dan rasional kurikulum.

2. Kegiatan selanjutnya adalah pemaparan materi tentang model-model pembelajaran dalam kurikulum 2013. Dalam model pembelajaran terdapat strategi pendekatan, metode, dan teknik pembelajaran dalam hal ini tentulah yang sesuai dengan konsep kurikulum 2013 yang dibagi menjadi tiga jenis, yaitu Model Pembelajaran Berbasis Proyek,

3. Tahap ketiga memaparkan materi tentang penguatan pengembangan soal diagnostik sebagai penguatan penilaian aspek kognitif

4. Tahap keempat ini diberikan materi tentang penyusunan Rencana Pelaksanaan Pembelajaran (RPP). Para Peserta juga diberikan materi Hardcopy materi tersebut selain slide powerpoint yang ditampilkan dihadapan para peserta.

5. Tahap kelima para peserta dipersilakan untuk bertanya tentang materi yang telah disampaikan terkait Kurikulum 2013.

6. Tahap terakhir kegiatan adalah tim pengabdian membagi para peserta dalam beberapa kelompok guna menyusun perangkat pembelajaran yang sesuai dengan kurikulum 2013.

Setelah selesai menyusun perangkat pembelajaran para peserta dari perwakilan kelompok diminta presentasi. Hambatan selama kegiatan adalahmasih kurangnya pengetahuanpeserta terhadap Kurikulum 2013,akibatnya peserta masih banyakyang bingung. Selain itu sarana yang timgunakanseperti pengeras suarayangmasihkurang baik mengganggujalannya presentasi yang disampaikan dankurang maksimal. Dalampelaksanaanya juga kegiatan ini mendapat respon yangbaikdariparapeserta.Hal inidibuktikandengan seriusnya pesertadari awalhinggaakhir mengikuti kegiatanpelatihanini. Parapesertapunikut aktifdalam sesitanyajawab tentang materi pelatihankurikulum 2013. Hal ini merupakantanggapan yangbagus dalam kegiatanini. Tujuandari kegiatan pengabdianmasyarakat iniadalahsebagaimana yangtelah disebutkan sebelumnya yaitu memberikan pengetahuan tentang Kurikulum 2013 serta memahami betapa pentingnya memamahami rasional dan elemen.

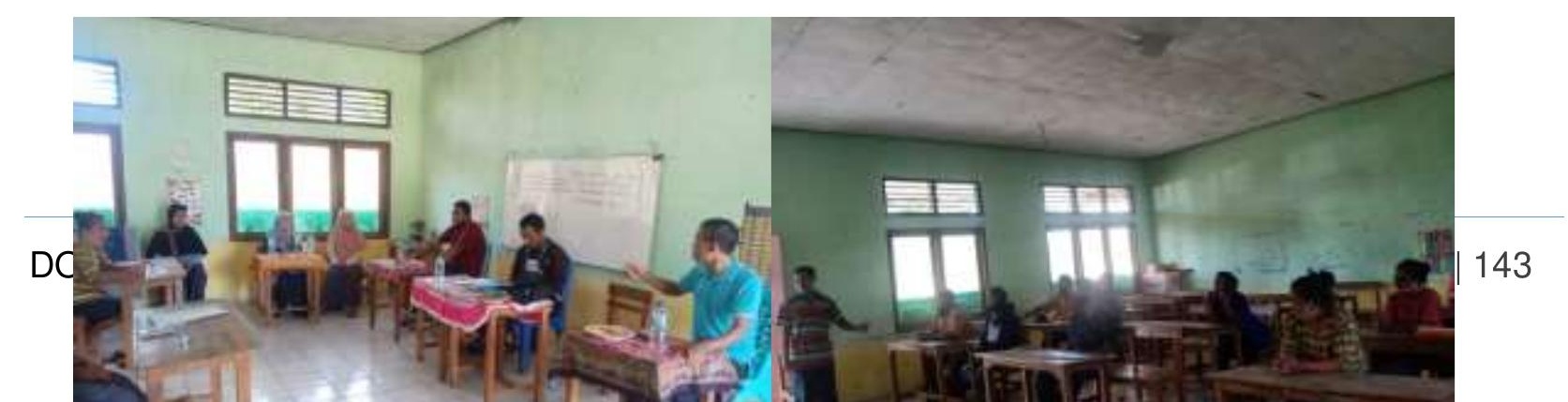


Gambar 1. Kegitan Pembukaan Pelatihan Kurikulum 2013 di SDI Fatukoan

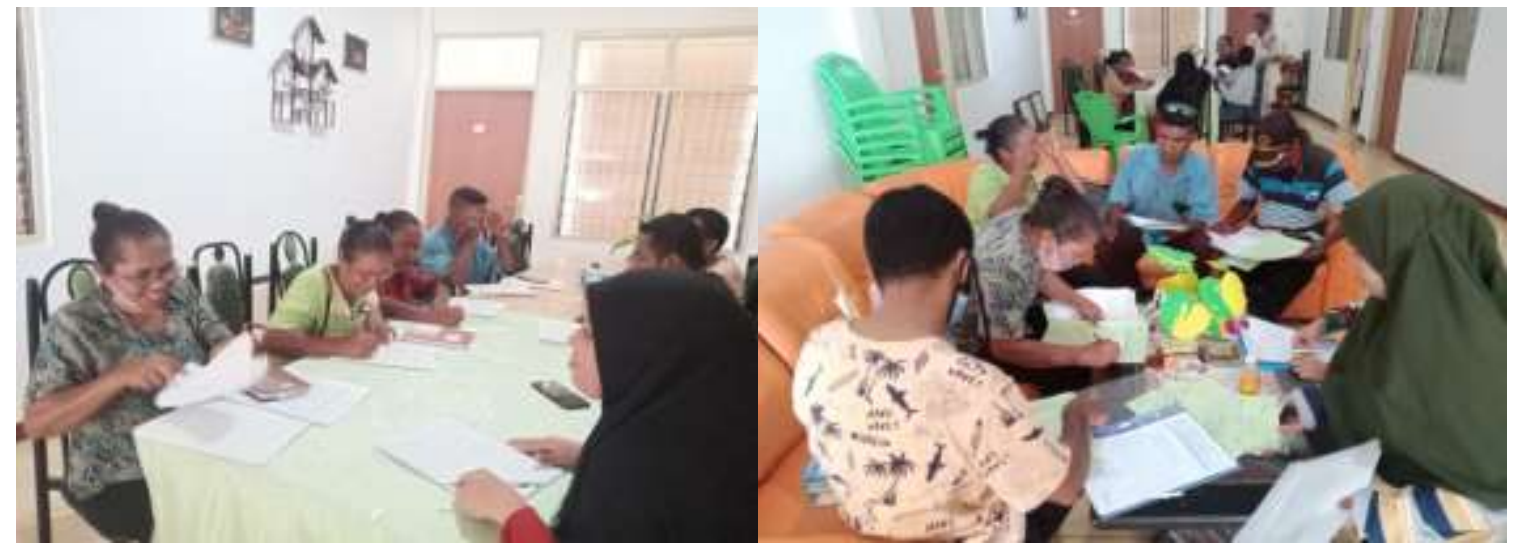

Gambar 2. Kegitan Pelatihan Kurikulum 2013 di SDI Fatukoan

\section{Pembahasan}

Langkah untuk mempersiapkan SDM dilakukan dengan sosialisasi dan pelatihan. Diklat Implementasi Kurikulum 2013 merupakan langkah awal yang sangat penting untuk mempercepat pemahaman dan keterampilan dalam mengimplementasikan kurikulum tersebut. Untuk memelihara dan meningkatkan kesinambungan pemahaman dan implementasi Kurikulum 2013 di masing-masing satuan pendidikan ,diprogramkan kegiatan pendampingan untuk para guru dan Kepala Sekolah (Abdul Syahril, 2020).

Kuncisukses dan kebermaknaan pembelajaran adalah kegiatan inti. Dalam kegiatan ini guru harus menggunakan metode yang bersesuaian dengan karakteristik siswa danmata pelajaran.Dalamkurikulum2013kegiatan intimencaku pproses-proses berikut:(1)melakukan observasi; (2) bertanya; (3)mengumpulkan informasi;(4) mengasosiasikan informasiinformasiyang telah diperoleh; dan (5) mengkomunikasikan hasilnya. Pada proses pembelajaran yang terkait dengan KD yang bersifat prosedur untuk melakukan sesuatu, guru memfasilitasi sedemikian rupa sehingga siswa dapat melakukan pengamatan terhadap pemodelan/demonstrasiyang diberikan guru atau ahli, siswa menirukannya, selanjutnya guru melakukan pengecekan dan pemberian umpan balik dan latihan lanjutan kepada siswa (Ummu et al., 2020). Hasil kegiatan pengabdian masyarakat ini di SDI Fatukoan banyak memberikan manfaat dan respon balikm yang sangat efektif terhadap guru dan peserta didik. 
Kurikulum 2013 disiapkan untuk mencetak generasi yang siap di dalam menghadapi tantangan masa depan. Oleh karenanya, pembelajaran di desain untuk mengoptimalkan daya nalar, daya kerja yang disertai dengan karakter yang mulia. Implementasi kurikulum dilengkapi dengan buku siswa dan pedoman guru yang disediakan oleh Pemerintah. Namun demikian pelaksanaan kurikulum 2013 juga memerlukan instrument berupa media pembelajaran, laboratorium, perpustakaan dan penunjang lainnya. Disamping itu buku juga merupakan instrumen penting dalam implementasi kurikulum 2013. Bagi guru buku merupakan petunjuk penting untuk mengembangkan proses belajar mengajar sebab kehadiran buku juga sangat diperlukan dalam menunjang keberhasilan pelaksanaan kurikulum 2013. (Nunie, 2015) mengemukakan bahwa Peran guru menjadi sorotan yang penting dalam implementasi kurikulum 2013, kompetensi guru sangat berpengaruh dalam penerapan Kurikulum 2013 meliputi wawasan Kurikulum 2013, perencanaan, pelaksanaan pembelajaran dan evaluasi hasil belajar. Ini dikarenakan guru berperan langsung dalam proses pembelajaran. Selain itu, kurangnya kemampuan guru dalam pemahaman konsep, perancangan Rencana Pelaksanaan Pembelajaran (RPP), penilaian dan pembuatan soal menjadikan perlunya evalausi tenaga pendidik.

\section{KESIMPULAN}

Hasil dari kegiatan pengabdian masyarakat ini yang dilakukan di SDI Fatukoan Kecamatan Rinhat Kabupaten Malaka yang dilaksanakanolehtim pengabdian masyarakatProgram StudiPendidikan Guru Sekolah Dasar FakultasKeguruan dan IImuPendidikan Universitas Muhammadiyah Kupang yang meliputi undang-undang/peraturan pemerintah tentang Kurikulum 2013, rasional kurikulum, materi penyusunan rencana pelaksana-an pembelajaranserta praktik pembuatanperangkat pembelajaran Kurikulum 2013 didapatkanbeberapa halseprti bertambahnya wawasan para guruyang adadilingkungan SDI Fatukoan tentang Kurikulum 2013.

\section{DAFTAR PUSTAKA}

Abdul Syahril, M. (2020). Evaluasi Program Komite Sekolah Dalam Rangka Meningkatkan Mutun Pendidikan Di SD Negeri Boleng Kecamatan Ileboleng Kabupaten Flores Timur. Jurnal Pendidikan Dasar Flobamorata, 1(1), 31-39.

lis, A., \& Wahyu, S. (2016). Pembelajaran Berbasis Proyek Untuk Meningkatkan Sikap IImiah Siswa Sekolah Dasar Pada Materi Peristiwa Alam. Jurnal Penelitian Pendidikan, 16(2), 167-176.

Muhammad, Y. (2019). Pelatihan Kurikulum 2013 Untuk Guru SD Di SD Islam Al Fatih Kecamatan Alalak Kabupaten Barito Kuala Kalimantan Selatan. Jurnal Pengabdian Masyarakat IImu Keguruan Dan Pendidkan, 2(1), 40-47. 
Nunie, S. (2015). Evaluasi Kompetensi Guru Dalam Mengimplementasikan Kurikulum 2013 Di SD Negeri Kejambon 2 Kota Tegal. Unne Repository. http://lib.unnes.ac.id/22419/

Suryadin, H., \& Arifin, A. (2020). Penerapan Pembelajaran Kooperatif Picture and Picture Bermedia Mind Map untuk Meningkatkan Kemampuan Literasi Sosoal Pada Peserta Didik Sekolah Dasar. Jurnal Basicedu, 4(3), 696-706.

Ummu, A., Suryadin, H., \& Uslan, U. (2020). The Influence of Process Oriented Guided Inquiry Learning (POGIL) Model Assisted by Realia Media to Improve Scientific Literacy and Critical Thinking Skill of Primary School Students. European Journal of Educational Research, 9(4), 1635-1647.

Uslan, U., Abdul, S. M., Julhidayat, M., Ummu, A., Dian, M., Muhammad, R. L., Suryadin, H., \& Rizqy, A. R. A. (2020). Science literacy empowerment for elementary school students at Kera Island Kupang Regency-East Nusa Tenggara. Journal of Community Service and Empowerment, 1(2), 86-92.

Yasinta, S., \& Ummu, A. (2020). Pengaruh Penggunaan Bahan Ajar Berbasis Kearifan Lokal Terhadap Penguasaan Konsep Siswa Kelas V di Sekolah Dasar. Prosiding Diskusi Daring Tematik 2020, Pendidikan Biologi Universitas Muhammadiyah Malang, 1(1). 